\title{
Combining ecological knowledge with Brazilian urban zoning planning
}

\author{
Combinando conhecimento ecológico ao planejamento do zoneamento \\ urbano brasileiro
}

Tércio da Silva Melo[a,b,c] (D), João Vitor Lino Mota[a,d] (D), Nathália Diniz Bastos e Silveira[a,b] (D), Alessandra Rodrigues Santos de Andrade[b,c] (D), Marcelo Cesar Lima Peres[b] (D), Magno Lima Travassos de Oliveira[a,b,c] [D, Jacques Hubert Charles Delabie ${ }^{[b, c]}$ (])

\author{
[a] Universidade Federal da Bahia (UFBA), Programa de Pós-graduação em Ecologia, Salvador, BA, Brasil \\ [b] Universidade Católica do Salvador (UCSal), Centro de Ecologia e Conservação Animal, Salvador, BA, Brasil \\ [c] Laboratório de Mirmecologia, Convênio Universidade Estadual de Santa Cruz/Comissão Executiva do Plano da \\ Lavoura Cacaueira (UESC/CEPLAC), Itabuna, BA, Brasil \\ [d] Biocore Tecnologia e Soluções Ambientais, Salvador, BA, Brasil
}

How to cite: Melo, T. S., Mota, J. V. L., Silveira, N. D. B., Andrade, A. R. S., Peres, M. C. L., Oliveira, M. L. T., \& Delabie, J. H. C. (2020). Combining ecological knowledge with Brazilian urban zoning planning. urbe. Revista Brasileira de Gestão Urbana, 12, e20190135. https://doi.org/10.1590/2175-3369.012.e20190135

\begin{abstract}
Politicians and environmental professionals have pointed to the lack of scientific knowledge to support legislation for planning urban centers. Thus, this essay aims to provide ecological knowledge to assist politicians and environmental professionals in decision making regarding the Brazilian urban zoning. As a science, ecology provides the necessary knowledge to assist the creation of guidelines and standards for urban zoning. Specifically, landscape ecology shows different methods of work, which have as parameters the qualification and quantification of urban environments. These parameters can be used as criteria for planning sustainable cities. The field of urban ecology has demonstrated the importance of conserving green and blue areas (water bodies) in cities, as well as the need for the formation of multidisciplinary teams for urban management and elaboration of public policies pointed to zoning sustainability strategies. Generally, ecology show contributions that assist in the creation of guidelines and norms for Brazilian urban zoning. The suggestions provided through this essay are a starting point for improving the formulation of laws designed to develop and strengthen the legislation on Brazilian urban zoning.
\end{abstract}

Keywords: Environmental zoning. Environmental management. Urban planning. Landscape ecology. Urban ecology.

\section{Resumo}

Políticos e profissionais de meio ambiente têm apontado para a ausência de conhecimento científico para embasamento da legislação que dispõe sobre o planejamento urbano. Assim, o intuito desse ensaio é

TSM is master in Ecology and Biomonitoring, e-mail: terciosilvamelo@hotmail.com JVLM is master in Ecology and Biomonitoring, e-mail: joaovitormota@yahoo.com.br NDBS is master in Ecology and Biomonitoring, e-mail: nathydinizbio@gmail.com ARSA is doctor in Ecology, e-mail: alessandrabiologia@hotmail.com MCLP is doctor in Ecology, e-mail: marcelo.peres@pro.ucsal.br MLTO is master in Ecology and Biomonitoring, e-mail: magnotravassos@gmail.com JHCD is doctor in Entomology, e-mail: jacques.delabie@gmail.com 
disponibilizar conhecimento ecológico para auxiliar políticos e profissionais de meio ambiente na tomada de decisões relacionadas ao zoneamento urbano do Brasil. Como ciência, a ecologia disponibiliza o conhecimento necessário para auxiliar a criação de diretrizes e normas para o zoneamento urbano. Especificamente, a ecologia de paisagem aponta diferentes métodos de trabalho, que possuem parâmetros de qualificação e quantificação do ambiente urbano. Esses parâmetros podem ser utilizados como critérios para o planejamento de cidades sustentáveis. Já a ecologia urbana tem demonstrado a importância da conservação de áreas verdes e azuis (corpos de água) nas cidades, além da necessidade da formação de equipes transdisciplinares para uma gestão urbana e elaboração de políticas públicas que visem a estratégia de zoneamento sustentável. De modo geral, a ciência da ecologia demonstra contribuições que auxiliam na criação de diretrizes e normas para o zoneamento urbano brasileiro. As sugestões fornecidas através desse ensaio constituem um ponto de partida para a formulação de melhorias nas leis destinadas a desenvolver e fortalecer a legislação relativa ao zoneamento urbano brasileiro.

Palavras-chave: Zoneamento ambiental. Gestão ambiental. Planejamento urbano. Ecologia de paisagem. Ecologia urbana.

\section{Introduction}

The Ecological-Economic Zoning (EEZ) is one of the main environmental planning tools in Brazil (Brasil, 2012a). The EEZ directs territorial planning, supporting social and economic development without abandoning environmental issues related to sustainability (Santos \& Ranieri, 2013). Although the EEZ aims to inform personal and companies' activities from public or private sectors, when it comes to the question of state or municipality management, politicians and environmental managers neglect this important environmental instrument (Rech, 2013; Santos \& Ranieri, 2013).

The lack of interest to fulfill the EEZ is due to numerous and different normative regulations linked to it (Rech, 2013; Santos \& Ranieri, 2013); mainly municipal laws (known as Master Plans), which are often not consistent in terms of the zoning of cities. Although the EEZ has been regulated by federal law, it is known that urban land planning is carried out locally, that is, by municipal applicability (Souza, 2013). As a result, municipal laws related to urban zoning are often not complementary to federal legislation, and can create ineffective legislation curbing the planning and management of urban zoning (Rech, 2013). The inefficiency of current public policies related to zoning allows economic and social interests that are not always compatible with environmental conservation to have greater decision-making power, causing severe damage to it (Leonelli \& Campos, 2018; Rech, 2013).

Another factor related to a deficiency of the urban zoning in producing legislation beneficial to environmental conservation is the lack of scientific basis during the development of the guidelines and norms for Brazilian urban planning (Rech, 2013; Souza, 2013). In addition to supporting decision making related to zoning, scientific knowledge can assist in planning and management processes of Brazilian land occupation (Rech, 2013). Since urban zoning management is linked to the law, it is impracticable to conserve natural environment in cities without guidelines and norms (Rech, 2013). Thus, the acquisition of scientific knowledge can assist politicians in the drafting of legislation on urban zoning. In this context, ecological knowledge is essential when planning a sustainable city, through a structure of knowledge transmission that allows the integration of scientific, technical and cultural information (Leitão \& Ahern, 2002). So, ecology can provide knowledge that will help the creation of guidelines and norms for a sustainable Brazilian urban zoning. Thus, this essay aims to suggest an ecological approach as a tool for public policies and planning of urban zoning in Brazil, helping decision makers and environmental professionals to make their choices about land planning of cities. 


\section{Public policies related to EEZ}

In 1981, the fulfillment of environmental zoning was required by the Federal Law $\mathrm{n}$ - 6.938 (establishing the Política Nacional do Meio Ambiente - National Environment Policy), and at that time, the EEZ was primarily instituted as a Brazilian land planning tool (Brasil, 1981). In 2001, supported by Federal Law no 10.257 (City Statute), environmental zoning was once more established as an instrument of territorial organization, but focusing on urban environments (Brasil, 2001). It was also in the City Statute that Brazilian cities became obligated to promote municipal laws to reinforce environmental zoning, known as the Master Plan (Brasil, 2001). The Law no 10.257 also established an obligation to carry out Environmental Impact Studies as an instrument of urban planning (Brasil, 2001). In 2002 the Federal Decree no 4.297 established the obligation of the EEZ to divide the land into zones of importance for environmental conservation, such as: (1) potential sites for ecosystem services provision and natural resources; (2) environments sensitive to biodiversity loss, soil and water resources; (3) Ecological Corridors and (4) Conservation Units (Brasil, 2002). Lastly, only in 2007 through Federal Decree $\mathrm{n}$ - 6.288, the scales of the EEZ at national, macro-regional, state and local levels were defined (Brasil, 2007). Despite the existence of these four federal laws, none of them established norms to regulate urban zoning in Brazilian cities, and guarantee environmental conservation or guidelines allowing the comparison of urban occupation between cities. This regulation flaw at federal level makes it difficult to develop sustainable urban zoning in Brazil.

From the environmental point of view, the creation of the four federal laws was positive, giving visibility to urban environmental issues (Brasil, 1981, 2001, 2002, 2007), but unfortunately there were no effective actions to protect the green areas in cities (Haddad, 2015; Huang et al., 2018; Leonelli \& Campos, 2018; Figueiroa \& Scherer, 2016). Nowadays, the inefficiency of federal laws in establishing norms for urban zoning is easily perceived by analyzing the Brazilian capitals Master Plans (Table 1). These plans lack standards for city zones classification, either because they do not define the scale at which zoning was planned, or do not adequately determine the environmental criteria for zone division, as proposed by federal laws (Brasil, 2002, 2007). Following this perspective of lack of minimum standardization in the zoning of Brazilian cities, it is important to highlight that Brazil is divided into three levels of government: federal, state and municipal, and there are conflicts of interest between them. Federal, state and federal laws have priority over state and local laws due to rules set by the constitution. That is, municipal laws cannot contradict state and federal regulations, nor can state laws counter federal laws. The problem is that federal laws related to urban zoning have indicative characteristics (Paiva, 2019) instead of normative, hampering the defense of environmental interests. This scenario makes the laws fragile in relation to urban territorial planning (both in regulatory quality and policy stability), which makes Brazil internationally classified as a country with a high risk of environmental losses due to urban growth (Huang et al., 2018). In this context, since federal public policies on environmental zoning established normative criteria, imposing changes in state and local laws, it is expected an improvement in the sustainable development of cities.

Table 1 - List of Master Plans of Brazilian capitals

\begin{tabular}{|c|c|c|c|}
\hline State & Capital & Master Plans & Author and Year \\
\hline Acre & Rio Branco & Lei $n^{\circ} 1.611$ de 2006 & Rio Branco (2006) \\
\hline Alagoas & Maceió & Lei n' 5.486 de 2005 & Maceió (2005) \\
\hline Amapá & Macapá & Lei complementar $n^{\circ} 26$ de 2004 & Macapá (2004) \\
\hline Amazonas & Manaus & Lei complementar $n^{\circ} 2$ de 2014 & Manaus (2014) \\
\hline Bahia & Salvador & Lei no 9.069 de 2016 & Salvador (2016) \\
\hline Ceará & Fortaleza & Lei complementar nº 62 de 2009 & Fortaleza (2009) \\
\hline Distrito Federal & Brasília & Lei complementar n 803 de 2009 & Brasilia (2009) \\
\hline Espírito Santo & Vitória & Lei 9.271 de 2018 & Vitória (2018) \\
\hline Goiás & Goiânia & Lei complementar $n^{\circ} 171$ de 2007 & Goiânia (2007) \\
\hline Maranhão & São Luís & Lei $n^{\circ} 4.669$ de 2006 & São Luís (2006) \\
\hline Mato Grosso & Cuiabá & Lei complementar $n^{\circ} 150$ de 2007 & Cuiabá (2007) \\
\hline Mato Grosso do Sul & Campo Grande & Lei complementar n' 94 de 2006 & Campo Grande (2006 \\
\hline
\end{tabular}


Table 1 - Continued...

\begin{tabular}{|c|c|c|c|}
\hline State & Capital & Master Plans & Author and Year \\
\hline Minas Gerais & Belo Horizonte & Lei $n^{\circ} 11.181$ de 2019 & Belo Horizonte (2019) \\
\hline Pará & Belém & Lei $n^{\circ} 8.655$ de 2008 & Belém (2008) \\
\hline Paraíba & João Pessoa & Lei complementar n 3 de 1992 & João Pessoa (1992) \\
\hline Paraná & Curitiba & Lei $n^{\circ} 14.771$ de 2015 & Curitiba (2015) \\
\hline Pernambuco & Recife & Lei n ${ }^{\circ} 17.511$ de 2008 & Recife (2008) \\
\hline Piauí & Teresina & Lei $n^{\circ} 3.558$ de 2006 & Teresina (2006) \\
\hline Rio de Janeiro & Rio de Janeiro & Lei complementar $n^{\circ} 111$ de 2011 & Rio de Janeiro (2011) \\
\hline Rio Grande do Norte & Natal & Lei complementar n` 82 de 2007 & Natal, 2007 \\
\hline Rio Grande do Sul & Porto Alegre & Lei complementar n 434 de 1999 & Porto Alegre (1999) \\
\hline Rondônia & Porto Velho & Lei complementar $n^{\circ} 311$ de 2008 & Porto Velho (2008) \\
\hline Roraima & Boa Vista & Lei complementar no 924 de 2006 & Boa Vista (2006) \\
\hline Santa Catarina & Florianópolis & Lei complementar $n^{\circ} 482$ de 2014 & Florianópolis (2014) \\
\hline São Paulo & São Paulo & Lei $n^{\circ} 16.050$ de 2014 & São Paulo (2014) \\
\hline Sergipe & Aracaju & Lei complementar $n^{\circ} 42$ de 2000 & Aracaju (2000) \\
\hline Tocantins & Palmas & Lei complementar $n^{\circ} 4002018$ & Palmas (2007) \\
\hline
\end{tabular}

Source: Authors.

\section{Brazilian and international urban zoning}

In Brazil, urban land occupation planning is performed by the Master Plan, which foresees zoning (Santos, 2018). However, due to City Statute not predicting environmental analysis in urban territory (Souza, 2013), proposals available in Master Plans are legislative speeches, which are not effectively applied in practice (Santos, 2018). Quantitatively, many Master Plans incorporate zoning, but qualitatively this tool incorporation (zoning) was performed disjointed of the law, not considering the municipality capability to manage territorial planning (Santos, 2018). Despite the time that laws were created to plan the growth of cities at different levels of government (federal, state and municipal), Brazilian legislation is considered of low quality in regard to urban zoning (Huang et al., 2018). Few recent studies evaluate the relationship between urban zoning and environment (Barbosa \& Carvalho, 2010; Nakano \& Guastella, 2015). These studies tackled qualitative analysis of laws relationships and effectiveness for the environment, without quantitative evaluative metrics. Currently, there are reports of law violation (Master Plans) that aimed to protect the environment, such as: non-preservation of Permanent Preservation Areas (APP) (Ataide \& Melo, 2019; Koury \& Cavallari, 2018; Nunes et al., 2017), Conservation Units (UC) (Ataide \& Melo, 2019), and areas for calamity prevention (Figueiroa \& Scherer, 2016); as well as lack of integrated management between municipal and state interests (Master Plans vs River Basin Plans) (Peres \& Silva, 2013). However, there is also positive elements since the municipality of Teresina, capital of the state of Piauí, anticipates in its planning the promotion of economic growth associated to ecological awareness (e.g. concern with waste management and green areas, river conservation, environmental zoning, urban drainage and sanitation sewage) (Nascimento \& Gomes, 2018). In Rio Claro, municipality of the state of São Paulo, the use of urban hydrography as spatial scale of zoning unit was tested, predicting environmental impacts (Barbosa \& Carvalho, 2010). Similar applications were made in other municipalities in the state of São Paulo, despite the inefficiency of Master Plans in zone cities, where there is an integration between the executive (managers) and legislative (politicians) powers, discussing points of improvements in the urban zoning during the revision of the plans (Santos \& Ranieri, 2013).

Besides Master Plans, other legal instruments are used to assist land use planning in Brazilian cities, as the Watershed Plan, Integrative Coastal Management Plan, and local Agenda 21. Just as Master Plans, Watershed Plans and Integrative Coastal Management Plans diverge from legislation in different government levels, in addition of execution and management difficulties (Gomes-Junior, 2014; Malheiros et al., 2013; Oliveira \& Nicolodi, 2012; Porto \& Porto, 2008). Nevertheless, the elaboration of these documents has shown an integrative advance between society and government during its elaboration (Gomes-Junior, 2014; Malheiros et al., 2013; Oliveira \& Nicolodi, 2012; Porto \& Porto, 2008). Evaluations 
carried out related to local Agenda 21 have demonstrated the potential of this tool to implement the Master Plans and strengthen environmental policies at the municipal level (Brasil, 2011).

Even in other countries, with better regulatory policies related to land use planning (Huang et al., 2018), there is a lack of standards among municipalities, which also influences zoning quality (Gurran et al., 2015). As in Brazil, other countries have urban zoning as a planning tool in which cities are divided into geographic zones according to land size and use, avoiding land use incompatibility. However, unlike Brazil, in these countries (e.g. United States, Mexico, New Zealand and Uruguay), urban zoning is implanted and executed, ensuring proper land use and environmental protection (Delion et al., 2015; Huang et al., 2018). Yet, these countries are dedicated to the conservation of natural environments; provide investments on these areas' rehabilitation/regeneration, also promoting ecological connection increase (Attwell, 2000; Clarkson \& Kirby, 2016; Romero et al., 2001; Li et al., 2005). Thus, as important as generating more normative federal laws, is the fact that, at the municipal level, the Master Plans are effectively executed in compliance with environmental laws, ensuring environmental sustainability in Brazilian cities.

\section{The ecology in zoning}

Since the existence of Brazilian laws does not guarantee a sustainable urban zoning, due to lack of guiding principles, it is required to use scientific information that ensures the effectiveness and efficiency of cities urban planning (Rech, 2013). According to Brazilian law, the EEZ must be established at large spatial scales (Brasil, 2007) and the solutions suggested by ecology as a science for environmental planning and management of zoning must be applied at the same levels (Leitão \& Ahern, 2002). Thus, landscape ecology is an approach that provides the necessary knowledge to assist in the creation of guidelines and norms that help planning of urban zoning. This branch of ecology aims to utilize spatially explicit models, through the qualification and spatial quantification of landscape units (habitats), supported mainly by geotechnologies (Leitão \& Ahern, 2002). In this perspective, the landscape represents a set of habitats which offer favorable conditions for an organism or object of study (Metzger 2001). However, the set of landscape habitats can also be obtained based on territorial occupation plans, developed on broad spatial scales such as the ecosystem level (Leitão \& Ahern, 2002; Metzger, 2001). In addition, landscape ecology focuses on the interactions between spatial patterns and ecological processes (Metzger, 2001; Turner, 2005), and is concerned with anthropogenic influences on landscape and land management (Metzger, 2001).

Urban ecology is another approach that covers several disciplines and practical applications, with an increasing focus on promoting sustainability (McPhearson etal., 2016). This science can provide information on complex relationships between social, economic and ecological aspects (McPhearson et al., 2016), allowing the integrated management of the urban environment in a more sustainable way. From the land occupation planning and management aspect, urban ecology is a science that works with multidisciplinary teams in several areas of social and natural knowledge. Urban ecology provides opportunities to identify important infrastructure and habitats that contribute to environmental conservation in urban areas (McPhearson et al., 2016; Pincetl, 2015). Thus, landscape ecology and urban ecology are convergent disciplines allowing integration into urban planning and management among politicians, managers and environmental and social scientists. This convergence allows more effective guidelines and norms for environmental sustainability to be included in the legislation of urban zoning.

\section{Landscape ecology in urban planning}

A first advance in environmental zoning of the city is establishing a spatial scale for analysis, essential for a sustainable planning (Leitão \& Ahern, 2002). In Brazil, studies on environmental zoning have been firstly made in river basin scale (regional scale) (Rempel et al., 2008). Based on legislation, the EEZ in river basin proportion contemplates regional scales between 1:1.000.000 and 1:100.000 (Brasil, 2002, 
2007), which are inadequate for urban zoning. It is crucial highlight that urban landscape management demand ecological knowledge at least on local scale when aiming to attend environmental requirements (McPhearson et al, 2016). As for local scales (cities) the law establishes a reference scale of 1:100.000 or higher (Brasil, 2002, 2007). Therefore, due to the incapacity of state and municipal legislation to normalize and standardize urban zoning, federal laws should establish a single scale for the whole Brazilian territory. It should be a mandatory parameter, due to the importance of standardized urban zoning scale, allowing then compare planning and urban processes among different cities of the country. This standardization would permit that managers provide useful information that allows scientists to investigate it and become legal parameters useful to politicians.

A large number of studies were developed with landscape ecology for Brazil's EEZ. The majority of these studies aim to classify and quantify zones (landscape blotches), mainly in regional scales. A few others were developed in local scales and generated some method contribution for urban zoning through landscape ecology (Table 2).

Table 2 - Literature on urban zoning with contribution of landscape ecology methods for city planning

\begin{tabular}{cc}
\hline Contribution & Author and Year \\
\hline Methods for the creation of greenway & Giordano \& Riedel (2008) \\
Indication of conflict zones with legislation & Rempel et al. (2008) \\
Selection of locals for recovering through Graph theory & Tambosi \& Metzger (2013) \\
Integration of environmental and socioeconomic variables to classify landscape units & Freitas \& Santos (2014) \\
Indication of the amount of native vegetation for conservation & Sadeck et al. (2017) \\
Prioritization index to conserve urban fragments & Crouzeilles et al. (2014) \\
\hline
\end{tabular}

Source: Authors.

For urban planning, landscape ecology has shown the importance of maintaining a minimum proportion of one or more habitat types responsible for biodiversity conservation and ecosystem services (Fahrig, 2013; Tews et al., 2004). Therefore, the establishment of rules and regulations for the conservation of a minimum extent within a set of urban habitats, even those not considered as native vegetation remnants (e.g. parks and squares) or natural water bodies (e.g. artificial lakes), guarantees environmental conservation in Brazilian cities. The simple maintenance of a habitat fraction in a landscape has demonstrated high relevance for conservation, even in comparison to other factors such as size and isolation of these habitats (Fahrig, 2013). Studies suggest that maintaining $20 \%$ to $30 \%$ of native vegetation in modified landscapes is enough to conserve fauna and ecosystem services (BanksLeite et al., 2014; Fahrig, 2003; Metzger, 2010; Pardini et al., 2010), allowing a combination of economic, social and environmental use (Metzger, 2010). On the second hand, for cities, it is necessary to conserve $50 \%$ of native vegetation cover, or $30 \%$ cover when there is connectivity with natural areas (Crouzeilles et al., 2014). When native vegetation cover is below $30 \%$, actions of ecological restoration must be carried out for maintenance of ecological interests (e.g. ecosystemic services) in urban environments (Crouzeilles et al., 2014). Based on this, we believe that the insertion of suitable laws in public policies obliging cities to maintain a minimum rate of native habitats (at least $30 \%$ ) in these areas would improve the Brazilian EEZ and contribute to support sustainability goals.

At present, there are laws in Brazilian environmental legislation that partially guarantee the conservation of natural areas in such environments, such as Permanent Preservation Areas (APP) and UC (Brasil, 2000, 2012b). It is noteworthy that due to the importance of these areas (APPs and UCs), they must be fully maintained environments in cities, even if they represent more than $30 \%$ of the landscape. Studies in Brazil proposed an approach to maintain a proportion of native habitats in the landscapes as criteria for elaboration of the Brazilian forest code (Metzger, 2010) and greenway (Giordano \& Riedel, 2008), as well as requests for deforestation (Rigueira et al., 2013) and maintenance of urban riparian vegetation (Castro et al., 2018). Landscape ecology has indicated these vegetation areas as priorities for conservation 
within the urban environment, enabling unite human and environment demands (Mello et al., 2016). Despite a portion of areas of ecological interest are protected by law and although studies have shown the importance of natural habitats conservation, conflicts between legislation and landscape ecology in urban environments persist. Among these conflicts, there is no federal law that protects areas (habitats) threatened of ecosystemic resilience loss and still are explored (e.g. native habitats in regeneration) over cities. These threatened habitats can be classified by landscape ecology (Rempel et al., 2008) and its protection should be provided in legislation as in City Statute (Brasil, 2001). Thereby, the use of landscape ecology methods associated to legal impositions can reduce conflicts of interest between environmental and social areas, contributing to decision making by environmental managers.

To classify zones in cities, besides consider ecological information, it is necessary include social and economic variables in urban zoning (Freitas \& Santos, 2014; Sadeck et al., 2017). The inclusion of this information can be done through data spatialization, with geotechnologies attached to landscape ecology that assist areas classification (Freitas \& Santos, 2014). With an integrated data base (environmental, social and economic information), urban landscape can be categorized into four interest classes: consolidation, expansion, recovery and conservation (Sadeck et al., 2017). Zone categories in cities protects environmental interests (e.g. recovery and conservation), ensure social and economic benefits (e.g. consolidation and expansion), directing adequate places for services development and urban infrastructure, besides real estate speculation, avoiding environment degradation (Silva et al., 2013). Mapping interest zones integrating social and economic data allows reducing conflicts between environmental, social and economic sectors. In addition, integrated data reduces subjectivity in urban zoning proposals, aiding city planning standardization.

Furthermore, other methods (or metrics) that improve landscape quality for biodiversity, such as connectivity, for example, would be used. For connectivity, Graph theory has shown a particular importance in planning, indicating the most important areas to be maintained in the landscape (Forero-Medina \& Vieira, 2007; Tambosi \& Metzger, 2013). This method allows users to measure the effect of modifications on functional connectivity between fragments (e.g. the use of ecological corridors and/or steppingstones), or assess functional connectivity through loss or gain of habitats (Forero-Medina \& Vieira, 2007). Graph theory can be used yet in Brazil to establish the restoration prioritization in local scale, contributing to planning habitats to be restored in cities (Tambosi \& Metzger, 2013). Thus, it is an important tool for the consolidation and expansion of urban areas. Just as Graph theory aids connectivity in cities, greenways have important value by making the union between natural habitats, reducing the isolation between these environments (Frischenbruder \& Pellegrino, 2006; Giordano \& Riedel, 2008). Linked to environmental interests, the establishment of greenways across the city also demonstrates social utility, through cultural and aesthetic development, as well as the recreational use of these environments (Frischenbruder \& Pellegrino, 2006; Giordano \& Riedel, 2008). Thus, the use of tools such as Graph theory and the creation of greenways, besides improving the connectivity between natural habitats in Brazilian cities, also allow opportune issues related to culture and leisure in the urban landscape.

In short, studies in landscape ecology have indicated the necessity to define a spatial scale for urban zoning and allow the conservation of a minimal rate of natural habitats in Brazilian cities. In planning, it is important to include environmental, social and economic data in the analysis of landscape ecology, allowing a more precise classification of urban areas and avoiding conflicts of interest during decision making. Furthermore, landscape ecology tools should also be used to help improve connectivity between natural habitats in cities, determining areas to be preserved and restored. Due to the efficient processes of classification and quantification of habitats (Leitão \& Ahern, 2002), landscape ecology can help urban planning by suggesting the configuration and proportion of habitats, then contributing to define guidelines and standards that improve the Brazilian urban zoning.

\section{Urban ecology in cities management}

Environmental degradation is generally a consequence of human occupation, and for that reason there is a necessity that Brazil plans with criteria its territory occupation (Rech, 2013). It is important to 
emphasize that city management should not be done solely from the point of view of landscape structure, but human behavioral patterns should also be considered (Haddad, 2015; Pickett et al., 1997). Social scientists were ahead on this matter; however, the recognition of the urban landscape as a provider of many ecosystem services was delayed amongst natural history scientists, with studies of the urban environment increasing in recent decades (Wu, 2014; Pincetl, 2015; McPhearson et al., 2016). Most studies have focused on green spaces (non-waterproof areas of urban land, such as native vegetation patches, parks, squares, wastelands, yards and gardens) and blue spaces (water bodies such as rivers, natural and artificial lakes) (Pickett et al., 1997; Wu, 2014). These provide ecosystem services, habitats for organisms and economic and social benefits, positively impacting human welfare in urban environments (Wu, 2014). However, nonnatural green and blue spaces in Brazil (e.g. public squares, wastelands, backyards, artificial lakes) have been rarely pointed as having some interest in conservation (Rech, 2013). Historically neglected at an environmental point of view, the importance of these spaces is generally related to social and economic issues (Benini \& Martin; 2010; Loboda \& Angelis, 2005). Nevertheless, even in strict urban landscapes, green and blue spaces are especially in preserving biodiversity and ecosystemic services (Bargos \& Matias, 2011; Benini \& Martin, 2010; Loboda \& Angelis, 2005; Nielsen et al., 2014; Pickett et al., 1997; Wu, 2014). Thus, these non-natural habitats must have its creation and importance reinforced thanks to legislation, aiming to attend environmental, social and economic interests during urban zoning. Thus, during the planning of the use and occupation of Brazilian land, it is important that all categories of green and blue spaces appear as priorities for conservation, enhancing city sustainability.

The lack of integration and holistic management across the different sectors related to urban zoning is a contemporary problem, since most planning is focused on urban infrastructure (Brasil, 2001; Childers et al., 2014; Haddad, 2015). As a consequence, urban ecology has become transdisciplinary in terms of goals (sustainability-oriented), methodologies (from the natural and social sciences) and actors (scientists, managers and politicians) (Brasil, 2001; Wu, 2014), attempting to generate a more sustainable city. The current challenge for city management is to understand urban ecosystems through several approaches, but also to form a new generation of people able to think in interdisciplinary and multidisciplinary ways (Collins et al., 2000; McPhearson et al., 2016), enabling a sustainable creation of the EEZ. However, we need to make effective use of the knowledge already produced in cities so that research in urban ecology could suggest to politicians and managers the better way promoting biodiversity and ecosystem services conservation (Haddad, 2015; McPhearson et al., 2016). For that, a conceptual framework allows a better comprehension of how urban ecology may assist Brazilian city's zoning (Figure 1).

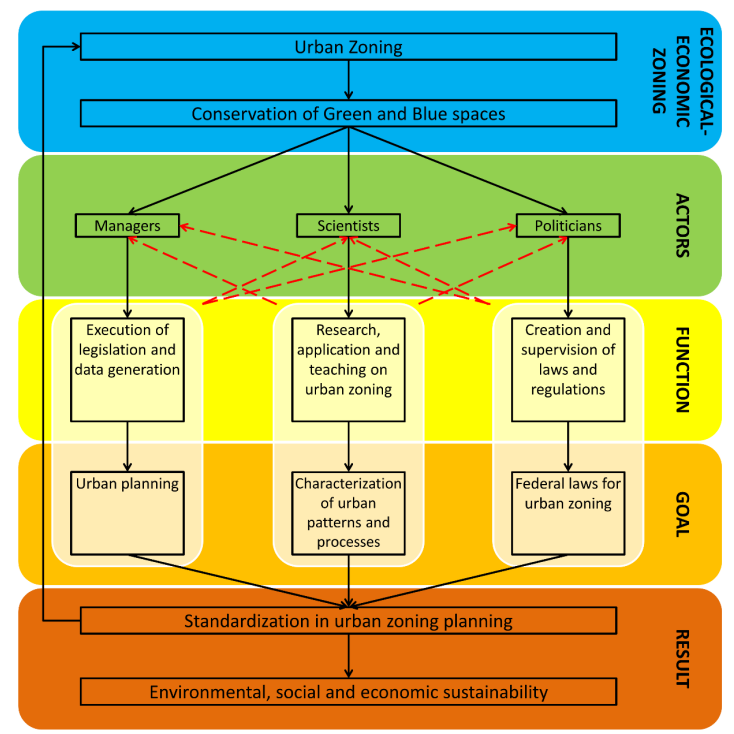

Figure 1 - Conceptual framework of how Brazilian urban zoning can be managed by different actors. Dashed lines indicate the expected transdisciplinary by urban ecology on the investigation process, development and execution of urban zoning among different actors. 
Although the urban zoning in Brazil is mainly the result of public policies, technical and scientific knowledge are essential for zoning to be adequate to the environmental and social reality of the city (Peres \& Silva, 2013; Souza, 2013). Within the EEZ, legislation related to urban zoning should prioritize the conservation of green and blue areas, regardless of the origin of the habitat (natural or artificial). For that purpose, managers, researchers and politicians must know and use information from other actors involved in the zoning, to properly exercise their functions and reach their goals. The joint work of the actors allows characterizing and standardizing urban zoning, supporting the planning of cities in a legal, technical and scientific manner. The data generated by the characterization and standardization of zoning support the formulation of laws related to planning. The final effect is the creation of unified legislation at national level establishing a minimal standardization of city planning that ensures the maintenance of social and environmental interests of the country and making the result of urban zoning prosperous (Rech, 2013). However, since the urbanization process is spatially and temporally dynamic, it is especially important that all obtained data are revised by those acting on cities' zoning (Peres \& Silva, 2013; Wu, 2014). This will allow ecological and social patterns to be uncovered, thereby helping to guide decisionmaking related to urban planning. Thus, a conceptual framework is an important tool of urban ecology that support standardization and comparison of zoning results between cities (McPhearson et al., 2016). Therefore, it is important that a minimum standard of the zoning exists for Brazilian cities, and that comparative criteria on urbanization in the country can be obtained to generate knowledge for planning and management of land use and occupation.

\section{Conclusion}

As a tool for a sustainable city planning, ecology allows relevant contributions, assisting in the creation of guidelines and norms for the Brazilian urban zoning. Notably, the field of landscape ecology has shown how geotechnologies, through the qualification and quantification of landscape elements, assist with territory occupation planning. In this section, the studies carried out in Brazil indicate its importance: (1) in the selection of a single spatial scale for Brazilian zoning; (2) maintenance of a minimum proportion of green and blue areas; (3) classification of zones in cities (consolidation, expansion, recovery and conservation); (4) methods of landscape analysis that improve connectivity (Graph theory and greenways) between different green areas in cities. Urban ecology has focused on promoting sustainability in cities, integrating several disciplines. This section of ecology integrates the management of urban zoning (through different political actors, managers and scientists), relating social, economic and ecological aspects. Through integrated information management, it is possible to identify Brazilian urban infrastructure and habitats important for the conservation of the environment and zoning of cities. Thus, broadly, ecology helps in urban zoning suggesting the types, proportions and configurations of urban habitats to be conserved, as well as helping in decision making for urban land planning.

This essay did not aim to modify the cities in the form they exist today since we recognize that this would present several huge challenges. Our main goal was to present a general overview for decision makers, such as environmental professionals and politicians, allowing highlighting the available research and scientific knowledge that could support the development of guidelines and minimum standards for a sustainable Brazilian urban zoning. The ideas presented herein are still schematic, but could provide a starting point for further improvements in urban zoning legislation.

\section{Acknowledgements}

This essay aimed to comply with the fulfillment of the class "History and Philosophy of Science Applied to Ecology", from the Ecology Postgraduate program of the Federal University of Bahia. We thank the contributions of anonymous reviewers. TSM thanks the PhD scholarship provided by CAPES. NDBS, ARSA 
and MLTO thank FAPESB for their PhD grant. The Catholic University of Salvador is fully acknowledged for its support extended to MCLP. JHCD acknowledges his research grant from CNPq.

\section{References}

Aracaju. (2000, 4 de outubro). Lei complementar no 42. Institui o Plano Diretor de desenvolvimento urbano de Aracaju, cria o sistema de planejamento e gestão urbana e dá outras providências. Aracajú: Diário Oficial do Município.

Ataide, R. M. C., \& Melo, N. A. (2019). Proteção Ambiental e Conflitos Territoriais: reflexões a partir das bordas metropolitanas de Natal/RN. In Anais do XVIII Encontro Nacional da Associação Nacional de Pós-graduação e Pesquisa em Planejamento Urbano e Regional (pp. 1-20). Natal: ENANPUR.

Attwell, K. (2000). Urban land resources and urban planting: case studies from Denmark. Landscape and Urban Planning, 52(2-3), 145-163. http://dx.doi.org/10.1016/S0169-2046(00)00129-8.

Banks-Leite, C., Pardini, R., Tambosi, L. R., Pearse, W. D., Bueno, A. A., Bruscagin, R. T., Condez, T. H., Dixo, M., Igari, A. T., Martensen, A. C., \& Metzger, J. P. (2014). Using ecological thresholds to evaluate the costs and benefits of setasides in a biodiversity hotspot. Science, 345(6200), 1041-1045. http://dx.doi.org/10.1126/science.1255768. PMid:25170150.

Barbosa, C., \& Carvalho, P. F. (2010). Zoneamento urbano-ambiental: possibilidades de compatibilização entre análise geomorfológica e padrões de ocupação urbanos para a construção de cidades sustentáveis. In Anais do VI Seminário Latino Americano de Geografia Física (pp. 1-13). Coimbra: Universidade de Coimbra.

Bargos, D. C., \& Matias, L. F. (2011). Áreas verdes urbanas: um estudo de revisão e proposta conceitual. REVSBAU, 6(3), 172-188. http://dx.doi.org/10.5380/revsbau.v6i3.66481.

Belém. (2008, 30 de julho). Lei no 8.655. Dispõe sobre o Plano Diretor do município de Belém, e dá outras providências. Belém: Diário Oficial do Município, 11189.

Belo Horizonte. (2019, 8 de agosto). Lei no 11.181. Aprova o Plano Diretor do Município de Belo Horizonte e dá outras providências. Belo Horizonte: Diário Oficial do Município, 5832.

Benini, S. M., \& Martin, E. S. (2010). Decifrando as áreas verdes públicas. Revista Formação, 17(2), 63-80.

Boa Vista. (2006, 28 de novembro). Lei complementar no 924. Dispõe sobre o Plano Diretor estratégico e participativo de Boa Vista e dá outras providências. Boa Vista: Diário Oficial do Município.

Brasil. (1981, 31 de agosto). Lei no 6.938. Dispõe sobre a Política Nacional do Meio Ambiente. Brasília: Diário Oficial da União, 119.

Brasil. (2000, 18 de julho). Lei no 9.985. Institui o Sistema Nacional de Unidades de Conservação da Natureza e dá outras providências. Brasília: Diário Oficial da União.

Brasil. (2001, 10 de julho). Lei no 10.257. Estabelece diretrizes gerais da política urbana e dá outras providências. Brasília: Diário Oficial da União.

Brasil. (2002, 10 de julho). Decreto no 4.297. Estabelecendo critérios para o Zoneamento Ecológico Econômico do Brasil. Brasília: Diário Oficial da União.

Brasil. (2007, 6 de dezembro). Decreto no 6.288. Dá nova redação ao art. $6^{o}$ e acresce os arts. ao Decreto no 4.297, de 10 de julho de 2002. Brasília: Diário Oficial da União.

Brasil. Ministério do Meio Ambiente - MMA. (2011). Agenda 21 Local Resultados Selecionados. Brasília: Secretaria de Articulação Institucional e Cidadania Ambiental Departamento de Cidadania e Responsabilidade Socioambiental (pp. 1-64). Brasília: MMA.

Brasil. (2012b, 25 de maio). Decreto nº 12.651. Dispõe sobre a proteção da vegetação native. Brasília: Diário Oficial da União. 
Brasil. Ministério do Meio Ambiente - MMA. (2012a). Instrumentos de planejamento. Brasília: MMA. Recuperado em 29 de maio de 2019, de http://www.mma.gov.br/cidades-sustentaveis/planejamento-ambientalurbano/instrumentos-de-planejamento

Brasília. (2009, 25 de abril). Lei complementar no 803. Aprova a revisão do Plano Diretor de Ordenamento Territorial do Distrito Federal - PDOT e dá outras providências. Brasília: Diário Oficial do Município.

Campo Grande. (2006, 6 de outubro). Lei complementar no 94. Institui a política de desenvolvimento e Plano Diretor de Campo Grande e dá outras providências. Campo Grande: Diário Oficial do Município.

Castro, S. L. I., May, L. R., \& Garcias, C. M. (2018). Meio ambiente e cidades - Áreas de Preservação Permanente (APPs) marginais urbanas na lei federal N. 12.651/12. Ciência Florestal, 28(3), 1340-1349.

http://dx.doi.org/10.5902/1980509833353.

Clarkson, B. D., \& Kirby, C. L. (2016). Ecological restoration in urban environments in New Zealand. Ecological Management \& Restoration, 17(3), 180-190. http://dx.doi.org/10.1111/emr.12229.

Collins, J. P., Kinzig, A., Grimm, N. B., Fagan, W. F., Hope, D., Wu, J., \& Borer, E. T. (2000). A new urban ecology. American Scientist, 88(5), 416-425. http://dx.doi.org/10.1511/2000.5.416.

Crouzeilles, R., Prevedello, J. A., Figueiredo, M. S. L., Lorini, M. L., \& Grelle, C. E. V. (2014). The effects of the number, size and isolation of patches along a gradient of native vegetation cover: how can we increment habitat availability? Landscape Ecology, 29(3), 479-489. http://dx.doi.org/10.1007/s10980-013-9978-6.

Cuiabá. (2007, 29 de janeiro). Lei complementar no ${ }^{\text {150 }}$. Dispõe sobre o plano diretor de desenvolvimento estratégico de Cuiabá e dá outras providências. Cuiabá: Diário Oficial do Município.

Curitiba. (2015, 17 de dezembro). Lei no 14.771. Dispõe sobre a revisão do Plano Diretor de Curitiba de acordo com o disposto no art. 40, $\S 3^{\circ}$, do Estatuto da Cidade, para orientação e controle do desenvolvimento integrado do município. Curitiba: Diário Oficial do Município.

Childers, D. L., Pickett, S. T. A., Grove, J. M., Ogden, L., \& Whitmer, A. (2014). Advancing urban sustainability theory and action: challenges and Opportunities. Landscape and Urban Planning, 125, 320-328.

http://dx.doi.org/10.1016/j.landurbplan.2014.01.022.

Delion, M. L., Hambarzumyan, A., Ibrahim, J., Farakos, A. M. S., \& Scanlan, M. (2015). Zoning and urban planning Understanding the benefits. In The World Bank (Ed.), Doing Business 2015 Going Beyond Efficiency. Washington: International Bank for Reconstruction and Development (12edição, p. 53-59). http://dx.doi.org/10.1596/978-14648-0351-2.

Fahrig, L. (2003). Effects of habitat fragmentation on biodiversity. Annual Review of Ecology Evolution and Systematics, 34(1), 487-515. http://dx.doi.org/10.1146/annurev.ecolsys.34.011802.132419.

Fahrig, L. (2013). Rethinking patch size and isolation effects: the habitat amount hypothesis. Journal of Biogeography, 40(9), 1649-1663. http://dx.doi.org/10.1111/jbi.12130.

Figueiroa, A. C., \& Scherer, M. E. (2016). Para onde estamos indo? Uma avaliação do plano diretor do Município de Florianópolis para o entorno da Estação Ecológica de Carijós. Desenvolvimento e Meio Ambiente, 38, 283-301. http://dx.doi.org/10.5380/dma.v38i0.47110.

Florianópolis. (2014, 17 de janeiro). Lei complementar no 482. Institui o Plano Diretor de urbanismo do município de Florianópolis que dispõe sobre a política de desenvolvimento urbano, o plano de uso e ocupação, os instrumentos urbanísticos e o sistema de gestão. Florianópolis: Diário Oficial do Município.

Forero-Medina, G., \& Vieira, M. V. (2007). Conectividade funcional e a importância da interação organismopaisagem. Oecologia Brasiliensis, 11(4), 493-502. http://dx.doi.org/10.4257/oeco.2007.1104.03.

Fortaleza. (2009, 13 de março). Lei complementar no 14.020. Institui o Plano Diretor participativo do município de Fortaleza e dá outras providências. Fortaleza: Diário Oficial do Município.

Freitas, M. W. D., \& Santos, J. R. (2014). Zoneamento hierárquico da paisagem nos domínios da bacia do Rio Uruguai. Sociedade \& Natureza, 26(2), 287-300. http://dx.doi.org/10.1590/1982-451320140207. 
Frischenbruder, M. T. M., \& Pellegrino, P. (2006). Using greenways to reclaim nature in Brazilian cities. Landscape and Urban Planning, 76(1-4), 67-78. http://dx.doi.org/10.1016/j.landurbplan.2004.09.043.

Giordano, L. C., \& Riedel, P. S. (2008). Multi-criteria spatial decision analysis for demarcation of greenway: a case study of the city of Rio Claro, São Paulo, Brazil. Landscape and Urban Planning, 84(3-4), 301-311. http://dx.doi.org/10.1016/j.landurbplan.2007.09.006.

Goiânia. (2007, 29 de maio). Lei complementar nº 171. Dispõe sobre o Plano Diretor e o processo de planejamento urbano do município de Goiânia e dá outras providências. Goiânia: Diário Oficial do Município.

Gomes-Junior, E. R. (2014). Estudo de caso da elaboração e implementação do plano de gestão integrada da orla marítima de Paripueira, Alagoas, Brasil (pp. 1-18). Belém: APP Urbana.

Gurran, N., Gilbert, C., \& Phibbs, P. (2015). Sustainable development control? Zoning and land use regulations for urban form, biodiversity conservation and green design in Australia. Journal of Environmental Planning and Management, 58(11), 1877-1902. http://dx.doi.org/10.1080/09640568.2014.967386.

Haddad, M. A. (2015). A framework for urban environmental planning in Brazil. Revista Europea de Estudios Latinoamericanos y del Caribe, (99), 113-125. http://dx.doi.org/10.18352/erlacs.10106.

Huang, C. W., McDonald, R. I., \& Seto, K. C. (2018). The importance of land governance for biodiversity conservation in an era of global urban expansion. Landscape and Urban Planning, 173, 44-50.

http://dx.doi.org/10.1016/j.landurbplan.2018.01.011.

João Pessoa. (1992, 30 de dezembro). Lei complementar nํㅜ 3. Institui o Plano Diretor da cidade de João Pessoa. João Pessoa: Diário Oficial do Município.

Koury, A. P., \& Cavallari, T. V. (2018). Desenvolvimento urbano em áreas de fronteira: o caso do Itaim Paulista. urbe. Revista Brasileira de Gestão Urbana, 10(3), 663-676. http://dx.doi.org/10.1590/2175-3369.010.003.ao13.

Leitão, A. B., \& Ahern, J. (2002). Applying landscape ecological concepts and metrics in sustainable landscape planning. Landscape and Urban Planning, 59(2), 65-93. http://dx.doi.org/10.1016/S0169-2046(02)00005-1.

Leonelli, G. C. V., \& Campos, E. F. R. (2018). Leis expansivas para a expansão urbana: campinas sem limites. Urbe. Revista Brasileira de Gestão Urbana, 10(Suppl 1), 36-48. http://dx.doi.org/10.1590/2175-3369.010.supl1.ao03.

Li, F., Wang, R., Paulussen, J., \& Liu, X. (2005). Comprehensive concept planning of urban greening based on ecological principles: a case study in Beijing, China. Landscape and Urban Planning, 72(4), 325-336. http://dx.doi.org/10.1016/j.landurbplan.2004.04.002.

Loboda, C. R., \& Angelis, B. L. D. (2005). Áreas verdes públicas urbanas: conceitos, usos e funções. Ambiência, 1(1), 125-139.

Macapá. (2004, 20 de janeiro). Lei complementar no 26. Institui o Plano Diretor de desenvolvimento urbano e ambiental do município de Macapá e dá outras providências. Macapá: Diário Oficial do Município.

Maceió. (2005, 30 de dezembro). Lei no 5.486. Institui o Plano Diretor do município de Maceió, estabelece diretrizes gerais de política de desenvolvimento urbano e dá outras providencias. Maceió: Diário Oficial do Município.

Malheiros, T. F., Prota, M. G., \& Ricón, M. A. P. (2013). Participação comunitária e implementação dos instrumentos de gestão da água em bacias hidrográficas. Revista Ambiente \& Água, 8(1), 98-118.

http://dx.doi.org/10.4136/ambi-agua.970.

Manaus. (2014, 16 de janeiro). Lei complementar nํ⒉ Dispõe sobre o Plano Diretor urbano e ambiental do município de Manaus e dá outras providências. Manaus: Diário Oficial do Município.

McPhearson, T., Pickett, S. T. A., Grimm, N. B., Niemelä, J., Alberti, M., Elmqvist, T., Weber, C., Haase, D., Breuste, J., \& Qureshi, S. (2016). Advancing urban ecology toward a science of cities. Bioscience, 66(3), 198-212. http://dx.doi.org/10.1093/biosci/biw002.

Mello, K., Toppa, R. H., \& Cardoso-Leite, E. (2016). Priority areas for forest conservation in an urban landscape at the transition between Atlantic Forest and Cerrado. Cerne, 22(3), 277-288.

http://dx.doi.org/10.1590/01047760201622032172. 
Metzger, J. P. (2001). 0 que é ecologia de paisagens? Biota Neotropica, 1(1), 1-9.

Metzger, J. P. (2010). 0 Código Florestal tem base científica? Natureza \& Conservação, 8(1), 92. http://dx.doi.org/10.4322/natcon.00801017.

Nakano, A. K., \& Guastella, S. A. (2015). A forma urbana a partir de planos diretores e leis de zoneamento do Município de São Paulo. Pesquisa em Arquitetura e Construção, 6(3), 142-154.

http://dx.doi.org/10.20396/parc.v6i3.8640799.

Nascimento, S. M. M. G., \& Gomes, J. M. A. (2018). Planejamento e orçamento municipal de Teresina para o crescimento econômico e meio ambiente no período de 2014 a 2016. Urbe. Revista Brasileira de Gestão Urbana, 10(3), 695-707. http://dx.doi.org/10.1590/2175-3369.010.003.ao15.

Natal. (2007, 21 de junho). Lei complementar nº 82. Dispõe sobre o Plano Diretor de Natal e dá outras providências. Natal: Diário Oficial do Município.

Nielsen, A. B., Van den Bosch, M., Maruthaveeran, S., \& Van den Bosch, C. K. (2014). Species richness in urban parks and its drivers: A review of empirical evidence. Urban Ecosystems, 17(1), 305-327.

http://dx.doi.org/10.1007/s11252-013-0316-1.

Nunes, H. K. B., Silva, J. F. A., \& Aquino, C. M. S. (2017). Código florestal (lei 12.651/2012) e zoneamento urbano de Teresina/PI: situação das areas de preservação permanente (APP's) do Rio Poti. In A. Perez, Fo., \& R. R. Amorim (Eds.), Os desafios da geografia na fronteira do conhecimento (pp. 6637-6648). Campinas: Instituto de Geociências, Universidade Estadual de Campinas. http://dx.doi.org/10.20396/sbgfa.v1i2017.1858.

Oliveira, M. R. L., \& Nicolodi, J. L. (2012). Gestão Costeira no Brasil e os dez anos do Projeto Orla. Uma análise sob a ótica do poder public. Revista da Gestão Costeira Integrada, 12(1), 89-98.

Paiva, G. B. (2019). Zoneameto Ecológico Econômico e Economia do zoneamento: uma revisão teórica. In Anais do XVIII Encontro Nacional da Associação Nacional de Pós-graduação e Pesquisa em Planejamento Urbano e Regional (pp. 1-20). Natal: ENANPUR.

Palmas. (2007, 28 de dezembro). Lei complementar nº 155. Dispõe sobre a política urbana do município de Palmas, formulada para atender ao pleno desenvolvimento das funções sociais da cidade e a garantia do bem-estar de seus habitantes, conforme estabelece a constituição federal/88, em seus arts. 182 e 183, e o estatuto da cidade, lei federal no 10.257, de 10 de julho de 2001. Palmas: Diário Oficial do Município.

Pardini, R., Bueno, A. A., Gardner, T. A., Prado, P. I., \& Metzger, J. P. (2010). Beyond the fragmentation threshold hypothesis: regime shifts in biodiversity across fragmented landscapes. PLoS One, 5(10), e13666. http://dx.doi.org/10.1371/journal.pone.0013666. PMid:21060870.

Peres, R. B., \& Silva, R. S. (2013). Interfaces da gestão ambiental urbana e gestão regional: análise da relação entre Planos Diretores Municipais e Planos de Bacia Hidrográfica. Urbe. Revista Brasileira de Gestão Urbana, 5(2), 13-25. http://dx.doi.org/10.7213/urbe.05.002.SE01.

Pickett, S. T. A., Burch, W. R., Jr., Dalton, S. E., Foresman, T. W., Grove, J. M., \& Rowntree, R. (1997). A conceptual framework for the study of human ecosystems in urban areas. Urban Ecosystems, 1(4), 185-199.

http://dx.doi.org/10.1023/A:1018531712889.

Pincetl, S. (2015). Cities as novel biomes: recognizing urban ecosystem services as anthropogenic. Frontiers in Ecology and Evolution, 3, 1-5. http://dx.doi.org/10.3389/fevo.2015.00140.

Porto Alegre. (1999, 24 de dezembro). Lei complementar no 434. Dispõe sobre o desenvolvimento urbano no município de Porto Alegre, institui o Plano Diretor de desenvolvimento urbano ambiental de Porto Alegre e dá outras providências. Porto Alegre: Diário Oficial do Município.

Porto Velho. (2008, 30 de junho). Lei complementar no 311. Dispõe sobre o Plano Diretor do município de Porto Velho e dá outras providências. Porto Velho: Diário Oficial do Município.

Porto, M. F. A., \& Porto, R. L. L. (2008). Gestão de bacias hidrográficas. Estudos Avançados, 22(63), 43-60. http://dx.doi.org/10.1590/S0103-40142008000200004. 
Recife. (2008, 29 de dezembro). Lei no 17.511. Promove a revisão do Plano Diretor do município do Recife. Recife: Diário Oficial do Município.

Rech, A. U. (2013). O zoneamento ambiental e urbanístico como instrumento de tutela efetiva e eficaz do meio ambiente. Veredas do Direito, 10(19), 93-222.

Rempel, C., Guerra, T., Porto, M. L., Périco, E., Eckhardt, R. R., \& Cemin, G. (2008). A ecologia da paisagem como base para o zoneamento ambiental da região político-administrativa - Vale do Taquari - RS - Brasil: um modelo de proposta metodológica. GeoFocus, 9, 102-125.

Rigueira, D. M. G., Coutinho, S. L., Pinto-Leite, C. M., Sarno, V. L. C., Estavillo, C., Campos, S., Dias, V. S., \& Chastinet, C. B. A. (2013). Perda de habitat, leis ambientais e conhecimento científico: proposta de critérios para a avaliação dos pedidos de supressão de vegetação. Revista Caititu, 1(1), 21-42. http://dx.doi.org/10.7724/caititu.2013.v1.n1.d03.

Rio Branco. (2006, 27 de outubro). Lei no 1.611. Aprova e institui o novo Plano Diretor do município de Rio Branco e dá outras providências. Rio Branco: Diário Oficial do Município.

Rio de Janeiro. (2011, 1 de fevereiro). Lei complementar no 111. Dispõe sobre a política urbana e ambiental do município, institui o Plano Diretor de desenvolvimento urbano sustentável do município do Rio De Janeiro e dá outras providências. Rio de Janeiro: Diário Oficial do Município.

Romero, H., Toledo, X., Órdenes, F., \& Vásquez, A. (2001). Ecología urbana y gestión ambiental sustentable de las ciudades intermedias chilenas. Ambiente y Desarrollo, 17(4), 45-51.

Sadeck, L. W. R., Lima, A. M. M., \& Adami, M. (2017). Artificial neural network for ecological-economic zoning as a tool for spatial planning. Pesquisa Agropecuária Brasileira, 52(11), 1050-1062. http://dx.doi.org/10.1590/s0100$204 \times 2017001100011$.

Salvador. (2016, 30 de junho). Lei no 9.069. Dispõe sobre o Plano Diretor de Desenvolvimento Urbano do município de Salvador - PDDU 2016 e dá outras providências. Salvador: Diário Oficial do Município.

Santos, L. G. S. (2018). Discurso × realidade: uma análise sobre a proposta de Zoneamento de Uso e Ocupação do solo no Plano Diretor de Desenvolvimento Municipal (PDDM) da cidade de Amargosa - Bahia (Dissertação de mestrado). Salvador: Faculdade de Arquitetura, Univesidade Federal da Bahia.

Santos, M. R. R., \& Ranieri, V. E. L. (2013). Critérios para análise do zoneamento ambiental como instrumento de planejamento e ordenamento territorial. Ambiente \& Sociedade, 16(4), 43-60. http://dx.doi.org/10.1590/S1414$753 \times 2013000400004$.

São Luís. (2006, 11 de outubro). Lei no 4.669. Dispõe sobre o plano diretor do município de São Luís e dá outras providências. São Luis: Diário Oficial do Município.

São Paulo. (2014, 31 de julho). Lei no 16.050. Aprova a política de desenvolvimento urbano e o Plano Diretor estratégico do município de São Paulo e revoga a lei no 13.430/2002. São Paulo: Diário Oficial do Município.

Silva, M. R. A., Maciel, L. S. C., Sobral, L. B. S., Moreira, M. F., Faria, R. V. R. A., \& Simões, U. O. (2013). Zoneamento ambiental: um estudo de caso do processo de uso e ocupação do solo no município de Uberlândia. Revista Eletrônica Geoaraguaia, 3(2), 318-342.

Souza, C. S. (2013). O papel do zoneamento ambiental no planejamento municipal. Revista de Propriedade Intelectual-Direito Econômico e Constituição, 4(1), 154-175. http://dx.doi.org/10.16928/2316-8080.V4N1p.154175.

Tambosi, L. R., \& Metzger, J. P. (2013). A framework for setting local restoration priorities based on landscape context. Natureza \& Conservação, 11(2), 152-157. http://dx.doi.org/10.4322/natcon.2013.024.

Teresina. (2006, 20 de outubro). Lei no 3.558. Reinstitui o Plano Diretor de Teresina, denominado Plano de Desenvolvimento Sustentável - Teresina Agenda 2015, e dá outras providências. Teresina: Diário Oficial do Município 1.124: 1-40. 
Tews, J., Brose, U., Grimm, V., Tielborger, K., Wichmann, M. C., Schwager, M., \& Jeltsch, F. (2004). Animal species diversity driven by habitat heterogeneity/diversity: the importance of keystone structures. Journal of Biogeography, 31(1), 79-92. http://dx.doi.org/10.1046/j.0305-0270.2003.00994.x.

Turner, M. G. (2005). Landscape ecology: what is the state of the science? Annual Review of Ecology Evolution and Systematics, 36(1), 319-344. http://dx.doi.org/10.1146/annurev.ecolsys.36.102003.152614.

Vitória. (2018, 22 de maio). Lei no 9.271. Aprova o Plano Diretor Urbano do Município de Vitoria e dá outras providências. Vitória: Diário Oficial do Município, 940, pp. 1-37.

$\mathrm{Wu}$, J. (2014). Urban ecology and sustainability: the state-of-the-science and future directions. Landscape and Urban Planning, 125, 209-221. http://dx.doi.org/10.1016/j.landurbplan.2014.01.018.

Editor: Harry Bollmann

Received: June 07, 2019

Approved: Aug. 10, 2020 